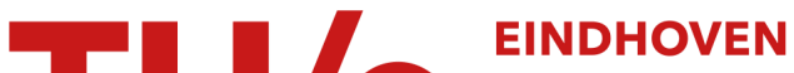 \\ UNIVERSITY OF \\ TECHNOLOGY
}

\section{Editorial : Learning from failures in game design for children}

Citation for published version (APA):

Moser, C., Tscheligi, M., Zaman, B., Vanden Abeele, V., Guerts, L., Vandewaetere, M., \& Markopoulos, P. (2014). Editorial : Learning from failures in game design for children. International Journal of Child-Computer Interaction, 2(2), 73-75. https://doi.org/10.1016/j.ijcci.2014.10.001

DOI:

10.1016/j.ijcci.2014.10.001

Document status and date:

Published: 01/01/2014

\section{Document Version:}

Publisher's PDF, also known as Version of Record (includes final page, issue and volume numbers)

\section{Please check the document version of this publication:}

- A submitted manuscript is the version of the article upon submission and before peer-review. There can be important differences between the submitted version and the official published version of record. People interested in the research are advised to contact the author for the final version of the publication, or visit the $\mathrm{DOI}$ to the publisher's website.

- The final author version and the galley proof are versions of the publication after peer review.

- The final published version features the final layout of the paper including the volume, issue and page numbers.

Link to publication

\section{General rights}

Copyright and moral rights for the publications made accessible in the public portal are retained by the authors and/or other copyright owners and it is a condition of accessing publications that users recognise and abide by the legal requirements associated with these rights.

- Users may download and print one copy of any publication from the public portal for the purpose of private study or research.

- You may not further distribute the material or use it for any profit-making activity or commercial gain

- You may freely distribute the URL identifying the publication in the public portal.

If the publication is distributed under the terms of Article 25fa of the Dutch Copyright Act, indicated by the "Taverne" license above, please follow below link for the End User Agreement:

www.tue.nl/taverne

Take down policy

If you believe that this document breaches copyright please contact us at:

openaccess@tue.nl

providing details and we will investigate your claim. 


\section{Editorial: Learning from failures in game design for children}

The game industry has been expanding exponentially in the past decades, mainly by making games more appealing to a wider audience. Initially, computer games were designed for the mass market. Nowadays, the game market has started to attract new audiences with different needs and skills. This resulted in a rapidly growing new generation of games with a serious purpose and real world relevance, beyond pure entertainment, e.g., to raise awareness, to influence attitudes and behavior, to transfer educational content, or train professional competences [1]. However, many of these 'serious' games for children have been criticized for being unable to achieve the goal of offering a compelling game experience (e.g., [2-4]). Furthermore, it is a well-established fact in academia and research that there is still a publication bias, when well-executed studies with null results (e.g., there is no significant differences), negative results, or disappointing results (effects that may be positive but of little practical significance) do not find their way into the archival literature (e.g., in medical informatics [5] or game studies on aggressive behavior [6]). While editorial decisions may definitely play a role, research has shown that the main cause is to be brought back onto the authors themselves, who seem to be hesitant about submitting negative results for publication [7].

The number of studies that provide a deeper understanding of the complex process of the design of games is limited. Consequently, mistakes that were made during the process of game design and development are likely to be repeated and the complexity of the design process is underestimated [1]. This is particularly true for serious games designed for children. The type of the games and the particularities of the envisioned target group confront researchers and designers with additional methodological, theoretical and procedural challenges. Therefore, this special issue will explicitly address the various challenges when designing games for and with children. We believe this special issue is timely, as game researchers and designers should be able to benefit from the insights gained through previous work and valuable lessons are shared. It will allow our young research field to mature more easily and engage in more ambitious future work that significantly contributes to the current body of knowledge on game design for children.

This special issue is the outcome of a workshop that was undertaken at the Conference on Human Factors in Computing Systems (CHI) 2013 [1]. A total of 18 researchers participated in the workshop with a wide range of game design related expertise, including but not limited to aspects as design, development, effectiveness, player experiences, child-friendliness, school-appropriateness, implementation, graphics, and project management. The workshop format was structured as a World Café (also called
Knowledge Café) [8], which is a simple, effective, and flexible format for hosting large group discussions. Through a critical reflection on failures and challenges encountered in (serious) game design research with and/or for children, we identified best practices and formulated lessons learned for each of the major design phases, including the requirements analysis, conceptualization, design, development, deployment, and validation phases. Throughout the workshop, the aim and motto became to "fail differently the next time". In the following, we briefly summarize the outcomes of the workshop. These were derived from game design projects with/for children, but might also be relevant for other projects as they mainly address more procedural and structural issues when developing with and for end users.

Requirements analysis: Based on our experiences in the requirements analysis phase, we learned that the particularities of project proposal writing often force project partners to promise more than they can realize. As there is a lot to gain during this initial phase (e.g., in terms of money, responsibilities, or ownership of the results), it is not unlikely that partners emphasize their expertise and strengths more than they confess their weaknesses. Therefore, our first lesson learned argues for transparency and concreteness from the very outset of a study, by making realistic promises (e.g., using concrete examples of what will be delivered) and presenting a fair overview of one's own strengths and weaknesses. By doing so, we will foster more successful collaborations in interdisciplinary game design teams where collaboration and feedback loops between the various stakeholders are the key to success.

Game conceptualization: The discussion on the game conceptualization phase has revealed the fact that often technology drives game projects, which seem to be pragmatic. For instance, technological components have to be ordered (and budgeted) at the beginning of the project and even some calls from funding agencies stipulate the use of certain types of technologies. Consequently, the game conceptualization tends to focus on the specifics of the technological features rather than a thorough discussion on what the developers should aim to design for. The underlying question is then whether the technology is only a means to an end or an end in itself. We argue that the discussions around the technologies should be reframed by answering the question to which extent it contributes to the design problem statement. Therefore, we advise future researchers to plan several feedback loops between the analysis and conceptualization phase in order not to be distracted by technological issues and maintain focus on the main design goal.

Game design: A lot of the discussions on the game design process were centered on the role of children and other end users in this phase. We learned that many researchers struggle with the balance 
between consulting end users to inform the design on one hand and deciding what to do with their input on the other. Our lesson learned is that we should not consider end users as equal design partners. Users do not always know what is best for them or do not have specialized (domain) knowledge that is required in (serious) game design. However, prioritizing the role of the game design experts does not mean that we should stop collaborating with end users.

Game development: Our discussions revealed that game developers understand and implement a game in terms of functions (i.e., the gameplay-balancing game controls, challenges, narrative, etc.) rather than tasks that end user should fulfill in the game (e.g., practice certain mathematic skills). For example, in the Monkey Tales game, children can practice mathematics in arcade games where a player has to divide the attention across different tasks such as solving the exercises as fast as possible but also avoiding slime that makes movements immobile for a few seconds in order to have a challenging game. To avoid misinterpretation due to a possible discrepancy, we advise all involved partners to sit together and discuss the game concept in detail in order to have a shared understanding of what should be developed in terms of tasks and how in terms of functions (goals vs. mechanics). Another issue that seems to occur very often is that game developers are not fully aware of the impact of (even small) design imposed upon the player (e.g., missing instructions). Therefore, we advise to plan sufficient player testing and closely involve the game developers in these evaluations so that the problems that can make a difference, in terms of player experience are found in early design stages and easily revised.

Game deployment: As for the game deployment, our discussion revealed that deployment is often not considered to be research and hence not budgeted or not sufficiently accounted for. However, game deployment is a crucial part of the game design process and of utmost importance for validation. Therefore, our advice is that if we cannot do it, it should be outsourced and a budget should be dedicated to do so. Additionally, it is important to be prepared that technology will not work or not be used in the intended way. Hence, another lesson learned is to design for human failure and prepare a back-up plan (with a feasible risk management strategy).

Game validation: So far, we are still facing too many user evaluation studies that lack sufficient depth and only describe "how the users liked it'. We encourage game researcher to evaluate (serious) games with scientific rigor, i.e., employing methods that have been validated to test games and involve children in this process. Additionally, not only short term but also long term effects need to be investigated (e.g., with repeated measurements). When experiencing the pressure to find a statistically significant effect, it is important to keep in mind that the validation phase is not primarily intended as a marketing tool but is part of the game design and development process. In order to investigate the ecological validity, it is important to combine qualitative and quantitative data and validate what children learned with the game (i.e., if requirements from the first phase were met).

The workshop called for submissions that enable learning from failures and challenges in serious game design with children. For this special issue, we selected three papers that report upon studies with experiences from using participatory design within serious game design, advancing the requirements analysis for serious games and investigating adaptive item sequencing to provide learning content adapted to the knowledge level of the learner:

- Participatory Design (PD) has become widely popular within the interaction design community with so far little influence within serious game design processes. Khaled and Vasalou share their experiences of using PD during the design process of a serious game (e.g., reflecting on the shortcomings of different methods and proposing a novel PD method that leverages two fundamental qualities of serious games, i.e., domain expertise and procedure, to scaffold players' knowledge and co-design serious games).

- A requirement analysis is needed before defining the scenarios of a serious game. In plenary sessions with the different stakeholders (i.e., coming from different disciplines and having different experiences), guidance is needed to have focused and effective sessions to identify and clarify many different issues that could influence the serious game. De Troyer and Janssens introduce a tablet app usable by non-technical stakeholders that they have developed to better support the requirement analysis phase.

- In order to provide adaptive gameplay that is based on learners' domain knowledge, accurate estimates of the difficulty of the content are required. However, estimates obtained via penand-paper ratings or via teacher ratings are not always reliable. The goal of the study of Maertens, Vandewaetere, Cornillie, and Desmet is to compare difficulty ratings from end users and experts in order to acquire reliable estimates of the difficulty of the mathematics rules offered in the game Monkey Tales. The results suggest a double format effect: not only the gaming format adds difficulty to educational content, but also the format the educational content is presented in a game is likely to add difficulty, which affects learners in-game performance.

Khaled and Ingram [9] illustrate the inherently messy nature and complex process of serious game design as a practice in terms of project organization, technology, domain knowledge, user research, and game design being essential for a successful (serious) game. The selected papers provide valuable insights in the complex process of designing serious games with/for children to learn from, in order to avoid researchers and practitioners repeating their past mistakes. We are aware that our lessons learned with children's games are more general and the selected papers are just a starting point for further discussions and contributions of the games community. For the future, we wish to see more reflections regarding failures and challenges (e.g., experienced when developing (serious) games for children, in contrast to success stories), methodological challenges and benefits (e.g., to get the different stakeholders involved as users, testers, informants, and design partners, or to validate a serious game), management issues (e.g., related to organizing or structuring the involvement of the different stakeholders), failure guidelines, or patterns.

\section{Acknowledgments}

Parts of the research are supported by the Austrian project "AIR-Advanced Interface Research", funded by the Austrian Research Promotion Agency (FFG), the ZIT Center for Innovation and Technology, the province of Salzburg under contract number 825345, and the Games@School project, funded by the Interdisciplinary Institute for Broadband Technology (iMinds) (grant number 110106), Flanders (Belgium).

\section{References}

[1] C. Moser, M. Tscheligi, B. Zaman, V. Vanden Abeele, L. Geurts, M. Vandewaetere, P. Markopoulos, P. Wyeth, J. Hofstätter, Let's talk about failures: why was the game for children not a success? in: Proc. EA CHI'13, ACM, New York, NY, USA, 2013, pp. 3199-3202.

[2] S. Egenfeldt-Nielsen, Beyond edutainment: exploring the educational potential of computer games (Doctoral thesis), IT-University of Copenhagen, Denmark, 2005.

[3] J. Kirriemuir, McFarlane, A Literature Review in Games and Learning, Futurelab, 2004.

[4] S. Papert, Does Easy Do It? Children, Games, and Learning, Game Developer (1998) 87-88. 
[5] C.P. Friedman, J.C. Wyatt, Publication bias in medical informatics, J. Am. Med. Inform. Assoc. 8 (2) (2001) 189-191.

[6] C.J. Ferguson, Evidence for publication bias in video game violence effects literature: A meta-analytic review, Aggression Violent Behav. 12 (4) (2007) $470-482$.

[7] K. Dickersin, Publication bias: Recognizing the problem, understanding its origins and scope, and preventing harm. Publication bias in meta-analysis: Prevention, assessment and adjustments, 2005, 11-33.

[8] J. Brown, D. Isaacs, W.C. Community, The World Café: Shaping Our Futures Through Conversations That Matter, Berrett-Koehler Publishers, 2005.

[9] R. Khaled, G. Ingram, Tales from the front lines of a large-scale serious game project, in: Proc. CHI'12, ACM, New York, NY, USA, 2012, pp. 69-78.

Christiane Moser*

Manfred Tscheligi

ICTES Center, University of Salzburg, Austria

E-mail addresses: christiane.moser@sbg.ac.at (C. Moser), manfred.tscheligi@sbg.ac.at (M. Tscheligi).

Bieke Zaman

CUO | Social Spaces, KU Leuven, iMinds, Belgium E-mail address: bieke.zaman@soc.kuleuven.be.
Vero Vanden Abeele

Luc Geurts

e-Media Lab, KU Leuven, Belgium

E-mail addresses: vero.vanden.abeele@kuleuven.be (B. Zaman), luc.geurts@kuleuven.be (V. Vanden Abeele).

Mieke Vandewaetere

ITEC, Interactive Technologies, KU Leuven, KULAK, iMinds, Belgium E-mail address: mieke.vandewaetere@kuleuven-kulak.be.

Panos Markopoulos Department of Industrial Design, Eindhoven University of Technology, Netherlands E-mail address: p.markopoulos@tue.nl.

Peta Wyeth Queensland University of Technology, Australia E-mail address: peta.wyeth@qut.edu.au.

* Corresponding editor. 